1 1

<)

PASTEK
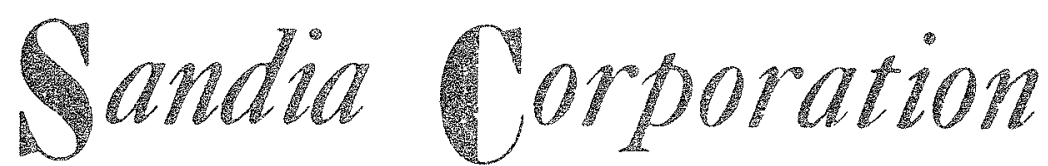

Contractor for U.S. Atomic Energy Commission ALBUQUERQUE, NEW MEXICO

LVERMORE, CALIFORMIA 


\section{DISCLAIMER}

This report was prepared as an account of work sponsored by an agency of the United States Government. Neither the United States Government nor any agency Thereof, nor any of their employees, makes any warranty, express or implied, or assumes any legal liability or responsibility for the accuracy, completeness, or usefulness of any information, apparatus, product, or process disclosed, or represents that its use would not infringe privately owned rights. Reference herein to any specific commercial product, process, or service by trade name, trademark, manufacturer, or otherwise does not necessarily constitute or imply its endorsement, recommendation, or favoring by the United States Government or any agency thereof. The views and opinions of authors expressed herein do not necessarily state or reflect those of the United States Government or any agency thereof. 


\section{DISCLAIMER}

Portions of this document may be illegible in electronic image products. Images are produced from the best available original document. 
(TID-4500 18th Ed。)

UC-25 METALS, CERAMICS, AND MATERIALS

$\mathrm{SC}-4747(\mathrm{RR})$

THREE LOW-PRESSURE SPALL THRESHOLDS IN COPPER

J. H. Smith, $1113^{*}$

January 1963

ABSTRACT

Measured values of the three low-pressure spall thresholds in copper plate are presented. The two lower thresholds are original with this program. However, the incipient spall threshold or beginning of tensile damage corresponds rather closely in magnitude to the dynamic elastic yield strength of copper in compression. The complete spall threshold corresponds to the value determined by Rinehart ${ }^{1}$ for copper.

Thresholds are presented in terms of pressure and pulse-width, and the effect of varying the pulsewidth with a given pressure is shown.

The experimental methods, including properties of the compressed-air gun, are discussed since they are applicable to most metals and many nonmetals.

\footnotetext{
*Now 7132
} 
Issued by Sandia Corporation, a prime contractor to the

United States Atomic Energy Commission

\section{LE CAL NOTICE}

This report was prepared as an account of Government sponsored work. Neither the United States, nor the Commission, nor any person acting on behalf of the Commission:

A. Makes any warranty or representation, expressed or implied, with respect to the accuracy, completeness, or usefulness of the information contained in this report, or that the use of any information, apparatus, method, or process disclosed in this report may not infringe privately owned rights; or

B. Assumes any liabilities with respect to the use of, or for damages resulting from the use of any information, apparatus, method, or process disclosed in this report.

As used in the above, "person acting on behalf of the Commission" includes any employee or contractor of the Commission, or employee of such contractor, to the extent that such employee or contractor of the Commission, or employee of such contractor prepares, disseminates, or provides access to, any information pursuant to his employment or contract with the Commission, or his employment with such contractor.

\footnotetext{
Printed in USA. Price $\$ 0.75$. Available from the Office of Technical Services, Department of Commerce, Washington $25, \mathrm{D}, \mathrm{C}$.
} 


\section{ACKNOWLEDGMENT}

Many people gave aid and inspiration for this project. In particular, the author acknowledges the following:

C. D. Lundergan made the excellent experimental facility available and contributed helpful discussions. shots.

R. E. Hollenbach and R. R. Williams prepared and aided in the firing of these

Photomicrographs and other metallurgical work were done by D. R. Adolphson, R. D. Bland, and $\mathrm{H}_{\text {。 }}$ Romero.

Mutual discussions with L。 M. Barker led to the tapered plug design and undoubtedly much of the other work.

An experiment by $J_{0} K_{0}$ Landauer of the Lawrence Radiation Laboratory prompted these spall experiments, except the spall prevention test which was extended from an experiment by R. K. Warner, also of the Lawrence Radiation Laboratory.

The multiplane experiments very likely came from discussions of K. N. Kreyenhagen's work at Aerojet General. 
-

- 


\section{TABLE OF CONTENTS}

Introduction

Discussion

Experimental Methods

Conclusions

APPENDIX A - - METALLURGY

20

APPENDIX B - SPALL PREVENTION

APPENDIX C - MISCELLANEOUS FIGURES

\section{LIST OF ILLUSTRATIONS}

\section{Figure}

$1 \quad$ Spall Thresholds

5 Residual Strength of Targets Using $1.5 \mu$ S Square Pulses

\section{LIST OF TABLES}

Table

I Thresholds for a Pulsewidth of About $11 / 2$ Microseconds

II Spall Thickness $\quad 14$

III Spall vs Impulse 
-

- 


\title{
THREE LOW-PRESSURE SPALL THRESHOLDS IN COPPER *
}

\author{
Introduction
}

When materials are compressed to pressures of tens of kilobars ${ }^{*}$ and then relieved to zero pressure, all within a few microseconds, spalling or scabbing often results. Spalling is the fracture of a material in tension caused by the interaction of two rarefaction waves.

Spalling can, of course, occur in varying degrees, thus leading to a total of four spall thresholds in copper, namely, the incipient, intermediate, complete, and ultimate spall thresholds (Figure 1). Moreover, these thresholds are somewhat dependent upon the type of copper used. Quantitative determination of the incipient and intermediate thresholds ${ }^{\dagger}$ is original with this program. However, the complete spall or detachment threshold as reported here is simply an edge-effect-free and, hence, lowered value of the threshold reported a decade ago by Rinehart, 1-3 The ultimate threshold, mentioned here for completeness, is well above the sixty kilobar upper limit of the present work, but has been observed by Dank, et al, ${ }^{4}$ McQueen and Marsh, 5 and Glass. 6

Spall studies provide: (1) realistic dynamic tensile strengths for design engineers, (2) a better understanding of solid state behavior, (3) data needed for many military applications, and (4) boundary conditions for equation of state programs in the negative pressure or tensile stress region.

Since 1912, when Bertram Hopkinson ${ }^{7}$ first explained spall, many experimenters $1-6,8$ have conducted spall studies. However, almost without exception these experimenters used high explosives and ultrahigh pressures with their inherent control difficulties.

In December 1959, this spall program was initiated with a compressed-air gun to impact flat plates together. In this manner, spall thresholds in copper were determined using one-dimensional, plane, square waves, and known pulse widths. Thresholds are given in terms of impulse rather than pressure alone, and the need for this refinement is demonstrated. Figure 2 shows increasing spall damage with increasing initial pulse width for a given pressure.

The techniques discussed here are economical and give more precisely known input conditions than are possible with high explosives. Perhaps most important, the techniques have been shown to apply to aluminum, copper, steel, and various plastics. Spall thresholds, perhaps including the ultimate, for any ordinary material can be accurately determined by applying the se techniques in conjunction with a high-velocity lightgas gun.

Discussion

\section{Wave Shapes in Use}

The tensile stress necessary to cause spall may be attained with two basically different wave shapes. Most observers use a pulse with a vertical shock front that is followed immediately by a sloping, exponential decay to zero pressure which continuously erodes the shock front. We might speak roughly of this as a "saw-tooth pulse." A pulse of this shape gives immediate tension when the vertical front reflects from a

\footnotetext{
* This work was done under the auspices of the AEC.

***

One kilobar $=14,500$ psi.

The intermediate threshold was determined by Dr. Walter Herrmann of MIT and is based on his
} analysis of spall samples from this program. See Reference 20. 


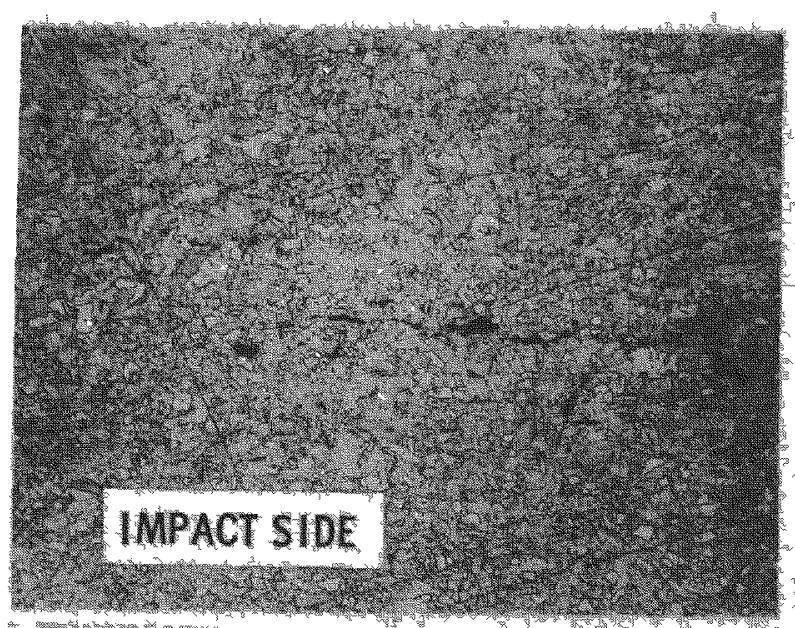

Incipient Spall

6 Kilobars, $115 \mathrm{ft} / \mathrm{sec}$

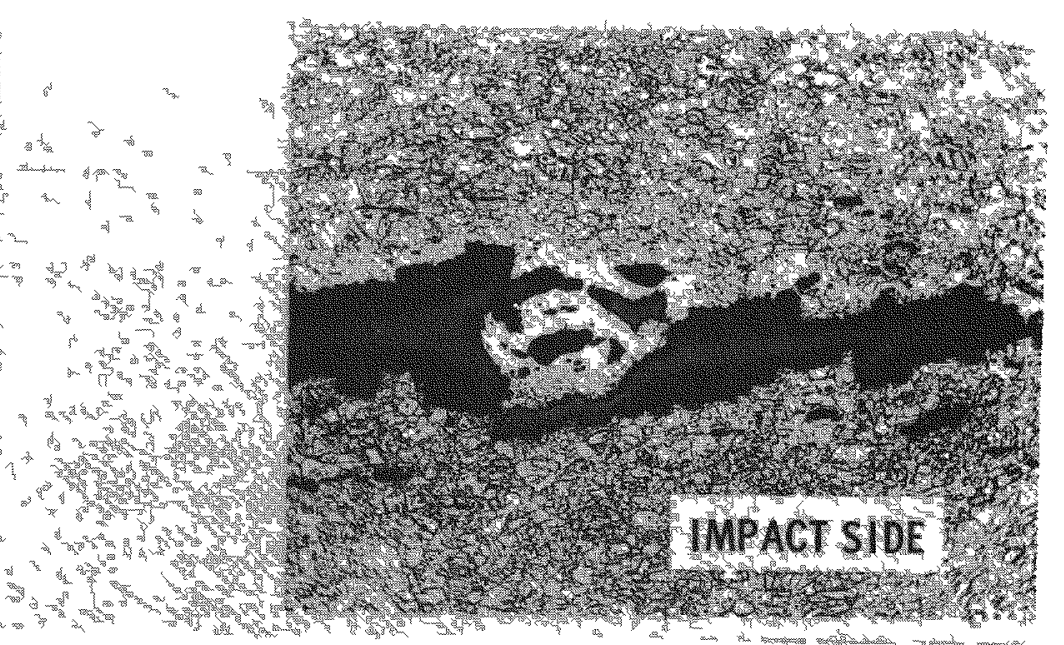

Intermediate Spall

16 Kilobars, $250 \mathrm{ft} / \mathrm{sec}$

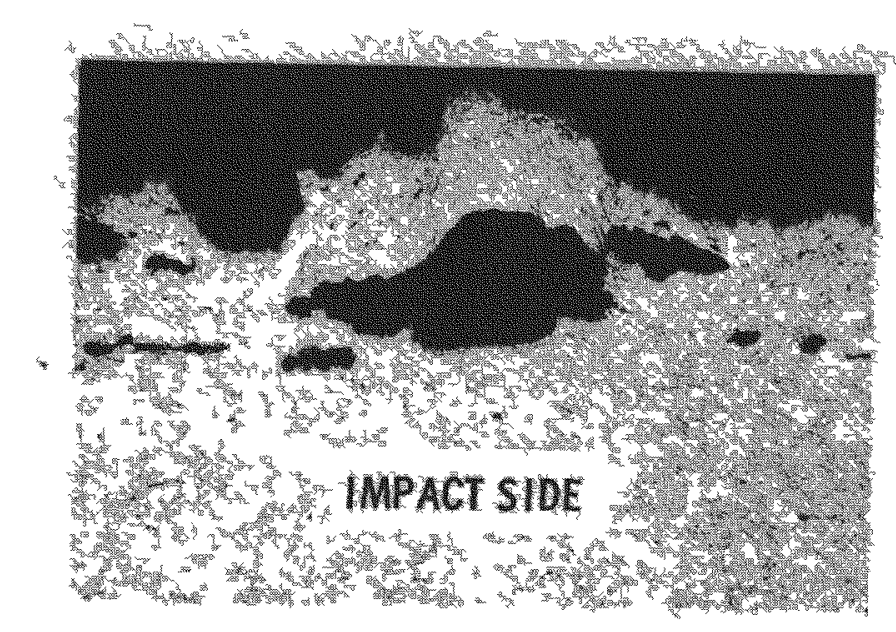

Complete Spall

22 Kilobars, $410 \mathrm{ft} / \mathrm{sec}$

Figure 1. Spall Thresholds

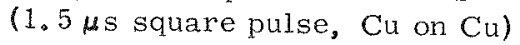




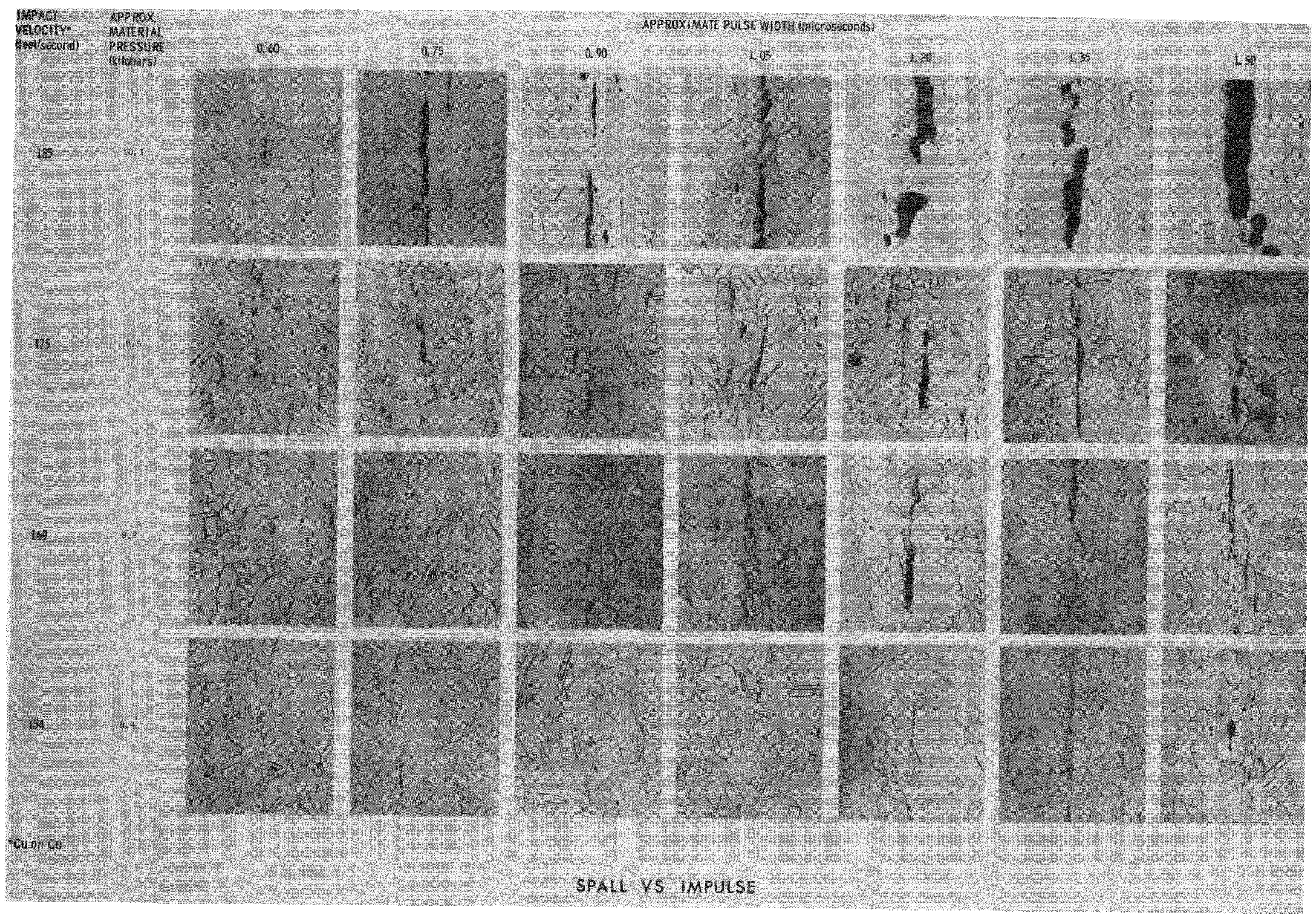


free-surface back into the trailing pressure release region or rarefaction. Pulses of this shape may be produced either by detonating high explosives directly on the target surface ${ }^{1-3}$ or by using high explosives to impact two plates at ultrahigh pressures where the initial square wave rapidly decays into a saw-tooth pulse. 5

The second distinct wave, and the one used throughout this program, is the constant square wave. This wave has a vertical shock front followed by a constant pressure plateau and then, in this low pressure region, a near vertical rarefaction to zero pressure. The shock front reflects from a zero impedance boundary or free surface as a rarefaction to zero pressure. Then, when this rarefaction and the rarefaction which followed the original shock propagate together and interact, tension is created.

In these experiments, propagation distances are short enough and pressures are low enough so that the square wave is maintained until well after spall time. Certainly, the trailing rarefaction does not overtake and exode the shock front. See Figurc 3 for an example of wave interactions with a square wave. For simplicity, the elastic precursor and the plastic shock wave are considered as one wave. The peak tension and the spall location are not affected by this simplification. However, if calculations of duration of tension were being attempted, the elastic precursor would have to be considered.

Once tension is produced in a material, by any method, spall in varying degrees occurs, depending " only on peak tension, duration of tension, and material properties. The inability to determine the duration of tension forces the use of the initial pulse width. Now let us discuss each of the three spall thresholds observed in this work. And for the sake of including all possible thresholds, we will also consider the ultimate threshold observed by others.

Nature of the Various Thresholds

According to the widely accepted Griffith theory 9,10 of fracture, brittle solids always contain microcracks. Applied stress concentrates at some of these microcracks, and, if the stress is of sufficient magnitude, causes them to grow into larger voids.

The incipient spall threshold is defined as the minimum pressure for a given pulse width which creates any visible spall fractures or voids. Obviously, whether a fracture is visible or not depends on how it is observed. In practice, these incipient spall fractures are found by polishing and cathodically etching (see Appendix A) the sample after a test. Then, any power of lens in the metallograph from $60 x$ on up is sufficient to resolve grain boundaries and incipient spall fractures. Using a higher power lens than 60X does not detect more voids, but simply enhances those found at the lower power. For example, a standard magnification of $100 \mathrm{X}$ was used for the photomicrographs shown here, but no more incipient spalls were observed than in earlier observations at 60X. In summary, the incipient spall threshold is the lowest pressure for a particular pulsewidth at which spall fractures on the order of a grain diameter occur.

The intermediate threshold is the pressure for a given pulse width for which the residual strength of the material takes on a constant value. This constant value of residual strength is maintained until the material has been subjected to the pressure necessary for complete spallation.

The intermediate threshold is clearly a later stage of damage than the incipient spall threshold. How ever, for the intermediate threshold, a greater density of microcracks start growing than at the lowerstress incipient spall threshold. This greater density decreases the distance a crack must travel to unite with another crack. In addition, microcracks get a much greater acceleration from the higher stress at the intermediate threshold. 11-13 Crack tip velocities may range from 40 to 90 percent of dilatational velocity. $14-15$

The third and last threshold determined in the present work is the complete spall threshold. This threshold is simply the pressure with a given pulse width for which detachment or complete separation of the spall piece occurs. Also, it is simply a later stage of damage than either of the first two thresholds. That is, more initial spall cracks are created and more crack propagation occurs. And, the small amount of material which is not severed by crack propagation may be sheared by momentum differences in the material. Rinehart ${ }^{1-3}$ found this threshold for copper to be slightly over 28 kilobars with an unspecified pulse width and unrelieved edge effects. 


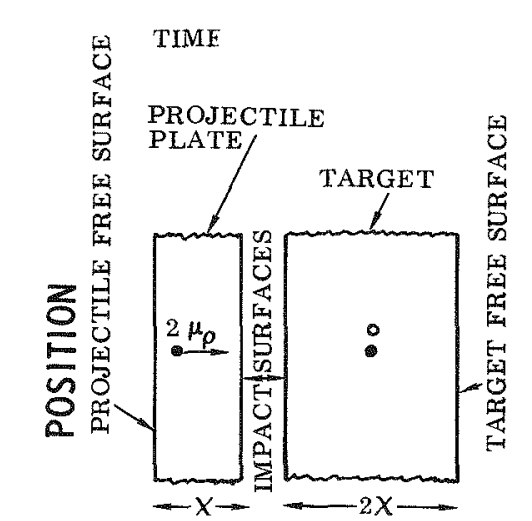

TIME II

TIME III

TIME IV

TIME V

\section{PROJECTILE}

PLATE TARGET
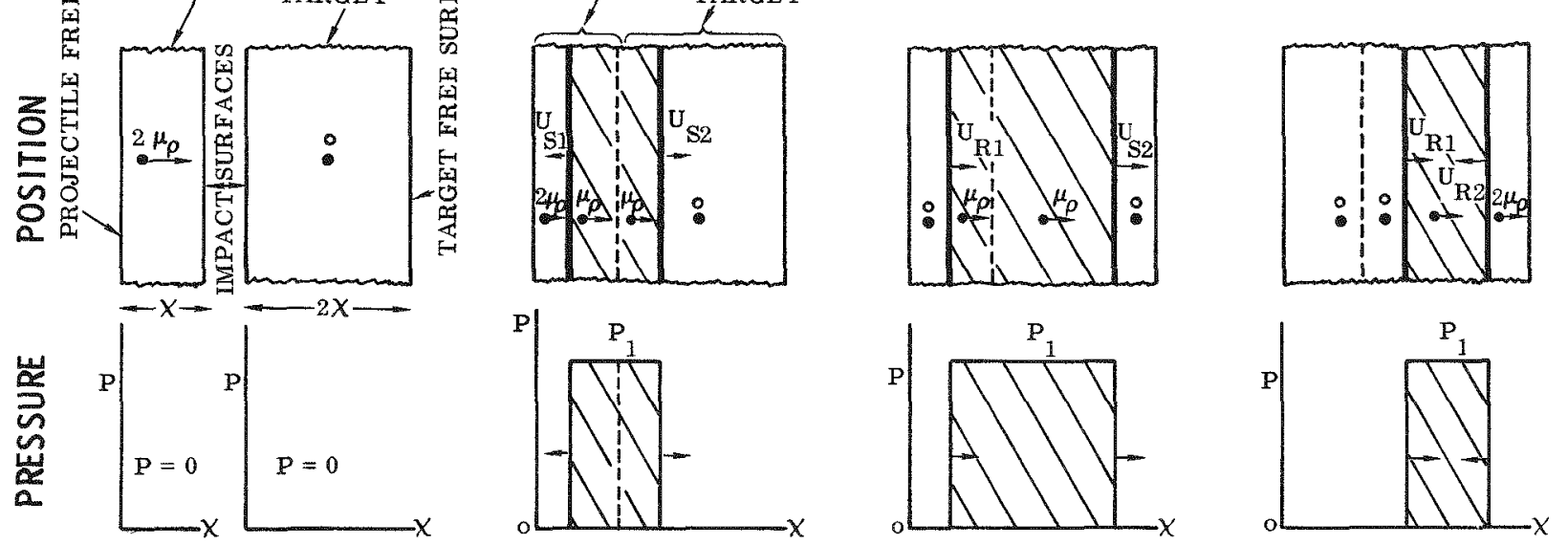

LEGEND :

\section{DIDV Material in compression}

Material in tension

WAVE INTERACTIONS FOR SPALI

Material under ambient pressure

WITH SINGLE SHOCK STRUCTURE

Rarefaction wave front

ront

Material velocity inparted by the shock

Material velocity imparted by

$2 \mu \rho \quad$ Original projectile velocity

- Material at rest with respect to the laboratory

NOTE

Pressure behind shock front

The elastic precursor is ignored, and the rarefaction and tension waves

are considered as shocks for this simplified analysis.

Figure 3. Example of Wave Interactions With a Square Wave 
These three thresholds are definitely rate or time dependent. Halving pulsewidths from $1-1 / 2$ to $3 / 4$ microseconds increased the incipient and complete thresholds by 3 or 4 kilobars. The intermediate threshold as yet has only been measured for the 1-1/2 microsecond pulse width. But even so, it seems clear that when one speaks of "yield pressure," a pulse width should be specified. See Table I, parts 1 and 2. Initial spall fractures occur in $10^{-8}$ or $10^{-9}$ seconds according to various theoreticians. But then the amount of damage occurring depends on how long the cracks are allowed to grow while this pressure is maintained。

TABLE I - PART 1

THRESHOLDS FOR A PULSEWIDTH OF ABOUT 1 1/2 MICROSECONDS

\begin{tabular}{|c|c|c|c|c|c|c|c|c|}
\hline Test & Projectile & Approximate & & EFF & $\mathrm{ECT}$ & & Projectile & Target \\
\hline No. & $\begin{array}{c}\text { Plate } \\
\text { Velocity } \\
\text { (ft/sec) }\end{array}$ & $\begin{array}{c}\text { Material } \\
\text { Pressure } \\
\text { (Kb.) }\end{array}$ & None & $\begin{array}{l}\text { Incipient } \\
\text { Spall }\end{array}$ & $\begin{array}{c}\text { Intermediate } \\
\text { Spall }\end{array}$ & $\begin{array}{c}\text { Complete } \\
\text { Spall }\end{array}$ & $\begin{array}{c}\text { Plate } \\
\text { Thickness } \\
\text { (in.) }\end{array}$ & $\begin{array}{l}\text { Thickness } \\
\text { (in.) }\end{array}$ \\
\hline 1 & 113 & 6.1 & & & & & 0.120 & 0.238 \\
\hline 2 & 125 & 6.8 & & . & & & 0.122 & 0.251 \\
\hline 3 & 133 & 7.2 & & & & & 0.115 & 0.253 \\
\hline 4 & 154 & 8.4 & & & & & 0.124 & 0.250 \\
\hline 5 & 169 & 9.2 & & & & & 0.124 & 0.194 \\
\hline 6 & 171 & 9.3 & & & & & 0.117 & 0.244 \\
\hline 7 & 175 & 9.5 & & & & & 0.123 & 0.194 \\
\hline 8 & 185 & 10.0 & & & & & 0.125 & 0.225 \\
\hline 9 & 249 & 13.5 & & & & & 0.118 & 0.226 \\
\hline & & & & In & termediate & & & \\
\hline 10 & 294 & 16.0 & & & & & 0.119 & 0.241 \\
\hline 11 & 326 & 17.7 & & & & & 0.115 & 0.235 \\
\hline 12 & 401 & 21.8 & & & & & 0.114 & 0.236 \\
\hline & & & & & & mplete & & \\
\hline 13 & 420 & 22.8 & & & & : & 0.138 & 0.256 \\
\hline 14 & 462 & 25.1 & & & & & 0.116 & 0.236 \\
\hline 15 & 463 & 25.1 & & & & & 0.120 & 0.239 \\
\hline 16 & 477 & 25.9 & & & & & 0.119 & 0.232 \\
\hline 17 & 493 & 26.7 & & & & & 0.122 & 0.256 \\
\hline 18 & 513 & 27.8 & & & & & 0.121 & 0.243 \\
\hline 19 & 580 & 31.5 & & & & & 0.132 & 0.238 \\
\hline 20 & 584 & 31.7 & & & & & 0.121 & 0.230 \\
\hline 21 & 674 & 36.6 & & & & & 0.119 & 0.231 \\
\hline 22 & 676 & 36.7 & & & & & 0.121 & 0.239 \\
\hline 23 & 728 & 39.5 & & & & & 0.120 & 0.231 \\
\hline 24 & 799 & 43.3 & & & & & 0.122 & 0.237 \\
\hline 25 & 832 & 45.1 & & & & & 0.117 & 0.240 \\
\hline 26 & 924 & 50.1 & & & & & 0.118 & 0.238 \\
\hline
\end{tabular}


TABLE I - PART 2

THRESHOLDS FOR A PULSEWIDTH OF ABOUT 3/4 MICROSECOND

\begin{tabular}{|c|c|c|c|c|c|c|c|}
\hline \multirow{2}{*}{$\begin{array}{l}\text { Test } \\
\text { No. }\end{array}$} & \multirow{2}{*}{$\begin{array}{c}\text { Projectile } \\
\text { Plate } \\
\text { Velocity } \\
\text { (ft/sec) }\end{array}$} & \multirow{2}{*}{$\begin{array}{l}\text { Approximate } \\
\text { Material } \\
\text { Pressure } \\
\text { (kb.) }\end{array}$} & \multicolumn{3}{|c|}{ EFFECh } & \multirow{2}{*}{$\begin{array}{l}\text { Projectile } \\
\text { Plate } \\
\text { Thickness } \\
\text { (in.) }\end{array}$} & \multirow{2}{*}{$\begin{array}{l}\text { Target } \\
\text { Thickness } \\
\text { (in.) }\end{array}$} \\
\hline & & & None & $\begin{array}{c}\text { Incipient } \\
\text { through } \\
\text { Intermediate } \\
\text { Spall } \\
\end{array}$ & $\begin{array}{c}\text { Complete } \\
\text { Spall }\end{array}$ & & \\
\hline 1 & 125 & 6.8 & 鑃 & & & 0.059 & 0.251 \\
\hline 2 & 154 & 8.4 & 㒛 & & & 0.062 & 0.250 \\
\hline \multirow[t]{2}{*}{3} & 169 & 9.2 & 1 & & & 0.061 & 0.194 \\
\hline & & & \multicolumn{2}{|c|}{ Incipient } & & & \\
\hline 4 & 175 & 9.5 & & & & 0.060 & 0.194 \\
\hline 5 & 178 & 9.7 & & & & 0.065 & 0.239 \\
\hline 6 & 185 & 10.0 & & & & 0.061 & 0.225 \\
\hline 7 & 268 & 14.5 & & & & 0.062 & 0.239 \\
\hline 8 & 462 & 25.1 & & & & 0.069 & 0.224 \\
\hline \multirow[t]{2}{*}{9} & 484 & 26.3 & & 14 & & 0.067 & 0.216 \\
\hline & & & & \multicolumn{2}{|c|}{ Complete } & & \\
\hline 10 & 502 & 27.2 & & & & 0.061 & 0.217 \\
\hline 11 & 539 & 29.2 & & & & 0.062 & 0.239 \\
\hline 12 & 592 & 32.1 & & & & 0.063 & 0.238 \\
\hline 13 & 693 & 37.6 & & & & 0.061 & 0.234 \\
\hline 14 & 726 & 39.4 & & & 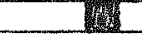 & 0.067 & 0.240 \\
\hline & & & & & & & \\
\hline & & & & & & & \\
\hline & & & & & & & \\
\hline & & & & & & & \\
\hline & & & & & & & \\
\hline
\end{tabular}

High above these thresholds that are strongly dependent upon crack propagation is a pressure and pulsewidth sufficient to cause initial spall fractures which detach the spall piece before any appreciable crack propagation can occur. In 1959, Dank, et al, 4 deduced by extrapolation that this ultimate spall threshold would be at about 160 kilobars. McQueen and Marsh 5 at Los Alamos and Glass 6 at the Ballistics Research Laboratory have measured this ultimate spall threshold in copper single crystals.

Experimental Methods

Air Gun and Instrumentation

A compressed-air gun with a 13-foot long barrel and a 4 -inch bore is used to accelerate the projectile plates to as much as $1100 \mathrm{feet} / \mathrm{second}$. Each projectile plate is glued around its periphery to a three-pound hollow-nosed foam-plastic cylinder which holds the plate normal to the axis of the gun barrel. Two "On rings on the plastic cylinder prevent the accelerating air from degrading the vacuum between the projectile and target plates.

The gun barrel and the vacuum cavity behind the projectile plate are evacuated to an initial vacuum of 10 microns. Subsequent compression from the projectile closing on the target is mitigated by an expansion reservoir around the muzzle of the barrel.

A simultaneity of impact averages $1 / 4$ microsecond per inch across the target. This deviation from normal impact is believed to have a negligible effect on spall results. 
Projectile velocity and asimultaneity are measured on each shot by a minimum-error, six-pin array of charged pins derived by Duff. 16 The pin closures are recorded with an oscilloscope and camera. Reference 17 gives the lengthy mathematics needed to reduce the pin data. However, a much simpler and more accurate way to measure projectile velocity, tilt, and tilt orientation is described in Reference 18.

\section{Targets and Projectile Plates}

Projectile plates are 3.8 -inch diameter flat plates of the thickness desired, with a 50 -microinch rms surface finish, and flat to within 0.0005 inch. In examining the effect of varied pulsewidths at precisely the same initial pressure, it is necessary to use multiplane" projectile plates.

The multiplane plates are essentially just seven flat regions of different thicknesses which impact a quarter-inch thick flat target plate. Because of the small differences in thicknesses (see Tables II and III and Figure 2), the scaling proposed by Trulio 19 is not deemed necessary.

All targets are 6.5-inch diameter, 1/4-inch thick flat plates with 50-microinch rms surface finishes. Flatness and parallelism are specified to 0.0005 inch. The large target diameters are needed for mounting on the gun and for holding measuring pins. The usable target diameter for spall observations is slightly over three inches. The usable diameter of the target equals the projectile plate diameter less the region influenced by edge effects which is roughly twice the target thickness.

Targets for accurately determining the complete spall threshold present a special problem. Simple flat plates do not allow the spalled region to detach without a lot of shearing long after spall time. Hence, targets were tried with a circular groove cut to the intended spall plane from the free surface side. This delineated the spalled piece and reduced edge shearing, but around the periphery of the spalled piece, near the groove, spalling was prevented. As evidence, the spalled piece was curved by the retardation at its edges. This, as we learned later, erroneously raised the complete spall threshold by two or three kilobars.

TABLE II

SPALL THICKNESS

\begin{tabular}{|c|c|c|c|c|c|c|}
\hline $\begin{array}{r}\text { Test } \\
\text { No. }\end{array}$ & $\begin{array}{l}\text { Projectile } \\
\text { Plate } \\
\text { Velocity } \\
\text { (ft/sec) }\end{array}$ & $\begin{array}{c}\text { Approximate } \\
\text { Material } \\
\text { Pressure } \\
(\mathrm{Kb} .) \\
\end{array}$ & $\begin{array}{l}\text { Target } \\
\text { Thickness } \\
\text { (in.) }\end{array}$ & $\begin{array}{c}\text { Projectile } \\
\text { Plate } \\
\text { Thickness } \\
\text { (in.) } \\
\end{array}$ & $\begin{array}{c}\text { Mean } \\
\text { Spall } \\
\text { Thickness }\end{array}$ & $\frac{\text { Projectile Plate Thickness* }}{\text { Mean Spall Thickness }}$ \\
\hline 1 & 420 & 22.8 & 0.256 & 0.138 & 0.130 & 1.06 \\
\hline 2 & 477 & 25.9 & 0.232 & 0.119 & 0.119 & 1.00 \\
\hline $3-1$ & 488 & 26.5 & 0.250 & 0.051 & 0.047 & 1.09 \\
\hline $3-2$ & 488 & 26.5 & 0.250 & 0.063 & 0.058 & 1.09 \\
\hline $3-3$ & 488 & 26.5 & 0.250 & 0.075 & 0.069 & 1.09 \\
\hline $3-4$ & 488 & 26.5 & 0.250 & 0.088 & 0.085 & 1.04 \\
\hline $3-5$ & 488 & 26.5 & 0.250 & 0.100 & 0.097 & 1.03 \\
\hline $3-6$ & 488 & 26.5 & 0.250 & 0.112 & 0.107 & 1.05 \\
\hline $3-7$ & 488 & 26.5 & 0.250 & 0.125 & 0.122 & 1.02 \\
\hline 4 & 493 & 26.7 & 0.256 & 0.122 & 0.121 & 1.01 \\
\hline 5 & $\approx 500$ & 27.1 & 0.248 & 0.120 & 0.120 & 1.00 \\
\hline 6 & 513 & 27.8 & 0.243 & 0.121 & 0.121 & 1.00 \\
\hline 7 & 580 & 31.5 & 0.238 & 0.132 & 0.133 & 0.99 \\
\hline 8 & 594 & 32.2 & 0.257 & 0.128 & 0.126 & 1.02 \\
\hline 9 & 674 & 36.6 & -0.231 & 0.119 & 0.122 & 0.98 \\
\hline 10 & 693 & 37,6 & 0.234 & 0.061 & 0.058 & 1.05 \\
\hline 11 & -700 & 38.0 & 0.247 & 0.120 & 0.119 & 1.01 \\
\hline 12 & 728 & 39.5 & 0.231 & 0.120 & 0.119 & 1.01 \\
\hline 13 & 832 & 45.1 & 0.240 & 0.117 & 0.117 & 1.00 \\
\hline & *Projectil & thickness & $1 / 2$ initi & pulse thic & kness & \\
\hline & & & & & & \\
\hline & & & & & & \\
\hline
\end{tabular}


TABLE III

SPALL VS IMPULSE

\begin{tabular}{|c|c|c|c|c|c|c|c|c|}
\hline \multirow{2}{*}{$\begin{array}{l}\text { Test } \\
\text { No. }\end{array}$} & \multirow{2}{*}{$\begin{array}{l}\text { Projectile } \\
\text { plare } \\
\text { Velocity } \\
\text { (ft/sec) }\end{array}$} & \multirow{2}{*}{$\begin{array}{l}\text { Target } \\
\text { Thickness } \\
\text { (in.) }\end{array}$} & \multirow{2}{*}{$\begin{array}{l}\text { Projectile } \\
\text { plate } \\
\text { Thickness } \\
\text { (in.) }\end{array}$} & \multicolumn{3}{|c|}{ EFFECT } & \multirow{2}{*}{$\begin{array}{c}\text { Approximate } \\
\text { Material } \\
\text { Pressure } \\
\text { (Kb.) }\end{array}$} & \multirow{2}{*}{$\begin{array}{c}\text { Approximate } \\
\text { Pulse } \\
\text { Width } \\
(\mu s)\end{array}$} \\
\hline & & & & None & $\begin{array}{l}\text { Incipient } \\
\text { through } \\
\text { Intermediate } \\
\text { Spall } \\
\end{array}$ & $\begin{array}{c}\text { Complete } \\
\text { spall }\end{array}$ & & \\
\hline $1-1$ & 488 & 0.253 & 0.125 & & & & 26.5 & 1.50 \\
\hline $1-2$ & 488 & 0.253 & 0.112 & & & & 26.5 & 1.35 \\
\hline $1-3$ & 488 & 0.253 & 0.100 & & & & 26.5 & 1.20 \\
\hline $1-4$ & 488 & 0.253 & 0.088 & & & & 26.5 & 1.05 \\
\hline $1-5$ & 488 & 0.253 & 0.075 & & & & 26.5 & 0.90 \\
\hline $1-6$ & 488 & 0.253 & 0.063 & & & & 26.5 & 0.75 \\
\hline $1-7$ & 488 & 0.253 & 0.051 & & & & 26.5 & 0.60 \\
\hline $2-1$ & 185 & 0.225 & 0.125 & & & & 10.0 & 1.50 \\
\hline $2-2$ & 185 & 0.225 & 0.111 & & & & 10.0 & 1.35 \\
\hline $2-3$ & 185 & 0.225 & 0.100 & & & & 10.0 & 1.20 \\
\hline $2-4$ & 185 & 0.225 & 0.088 & & & & 10.0 & 1.05 \\
\hline $2-5$ & 185 & 0.225 & 0.076 & & & & 10.0 & 0.90 \\
\hline $2-6$ & 185 & 0.225 & 0.061 & & & & 10.0 & 0.75 \\
\hline $2-7$ & 185 & 0.225 & 0.050 & & & & 10.0 & 0.60 \\
\hline $3-1$ & 175 & 0.194 & 0.123 & & & & 9.5 & 1.50 \\
\hline $3-2$ & 175 & 0.194 & 0.111 & & & & 9.5 & 1.35 \\
\hline $3-3$ & 175 & 0.194 & 0.099 & & & & 9.5 & 1.20 \\
\hline $3-4$ & 175 & 0.194 & 0.087 & & & & 9.5 & 1.05 \\
\hline $3-5$ & 175 & 0.194 & 0.073 & & & & 9.5 & 0.90 \\
\hline $3-6$ & 175 & 0.194 & 0.060 & & & & 9.5 & 0.75 \\
\hline $3-7$ & 175 & 0.194 & 0.049 & 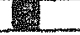 & & & 9.5 & 0.60 \\
\hline $4-1$ & 169 & 0.194 & 0.124 & & & & 9.2 & 1.50 \\
\hline $4-2$ & 169 & 0.194 & 0.111 & & & & 9.2 & 1.35 \\
\hline $4-3$ & 169 & 0.194 & 0.099 & & & & 9.2 & 1.20 \\
\hline $4-4$ & 169 & 0.194 & 0.088 & & & & 9.2 & 1.05 \\
\hline $4-5$ & 169 & 0.194 & 0.074 & & & & 9.2 & 0.90 \\
\hline $4-6$ & 169 & 0.194 & 0.061 & & & & 9.2 & 0.75 \\
\hline $4-7$ & 169 & 0.194 & 0.049 & & & & 9.2 & 0.60 \\
\hline $5-1$ & 154 & 0.250 & 0.124 & & & & 8.4 & 1.50 \\
\hline $5-2$ & 154 & 0.250 & 0.111 & & & & 8.4 & 1,35 \\
\hline $5-3$ & 154 & 0.250 & 0.098 & & & & 8.4 & 1.20 \\
\hline $5-4$ & 154 & 0.250 & 0.088 & & & & 8.4 & 1.05 \\
\hline $5-5$ & 154 & 0.250 & 0.072 & ${ }^{2}$ & & & 8.4 & 0.90 \\
\hline $5-6$ & 154 & 0.250 & 0.062 & & & & 8.4 & 0.75 \\
\hline $5-7$ & 154 & 0.250 & 0.049 & & & & 8.4 & 0.60 \\
\hline $6-1$ & 125 & 0.251 & 0.122 & & $F_{1}$ & & 6.8 & 1.50 \\
\hline $6-2$ & 125 & 0.251 & 0.108 & & & & 6.8 & 1.35 \\
\hline $6-3$ & 125 & 0.251 & 0.097 & & & & 6.8 & 1.20 \\
\hline $6-4$ & 125 & 0.251 & 0.084 & & & & 6.8 & 1.05 \\
\hline $6-5$ & 125 & 0.251 & 0.071 & & & & 6.8 & 0.90 \\
\hline $6-6$ & 125 & 0.251 & 0.059 & & & & 6.8 & 0.75 \\
\hline $6-7$ & 125 & 0.251 & 0.047 & & & & 6.8 & 0.60 \\
\hline & & & & & & & & \\
\hline
\end{tabular}


To eliminate this edge effect, a special tapered plug design was evolved. The center region of a flat plate is cut out on an angle of about 8 degrees with the normal such that the smaller diameter is on the impact side of the target. The outer portion or retaining ring is usable. But, because of machining losses, the inner plug is discarded. Then a new tapered plug is machined which fits precisely into the center of the retaining ring. The finished product appears to be a one-piece target. See Figure 4 for details.

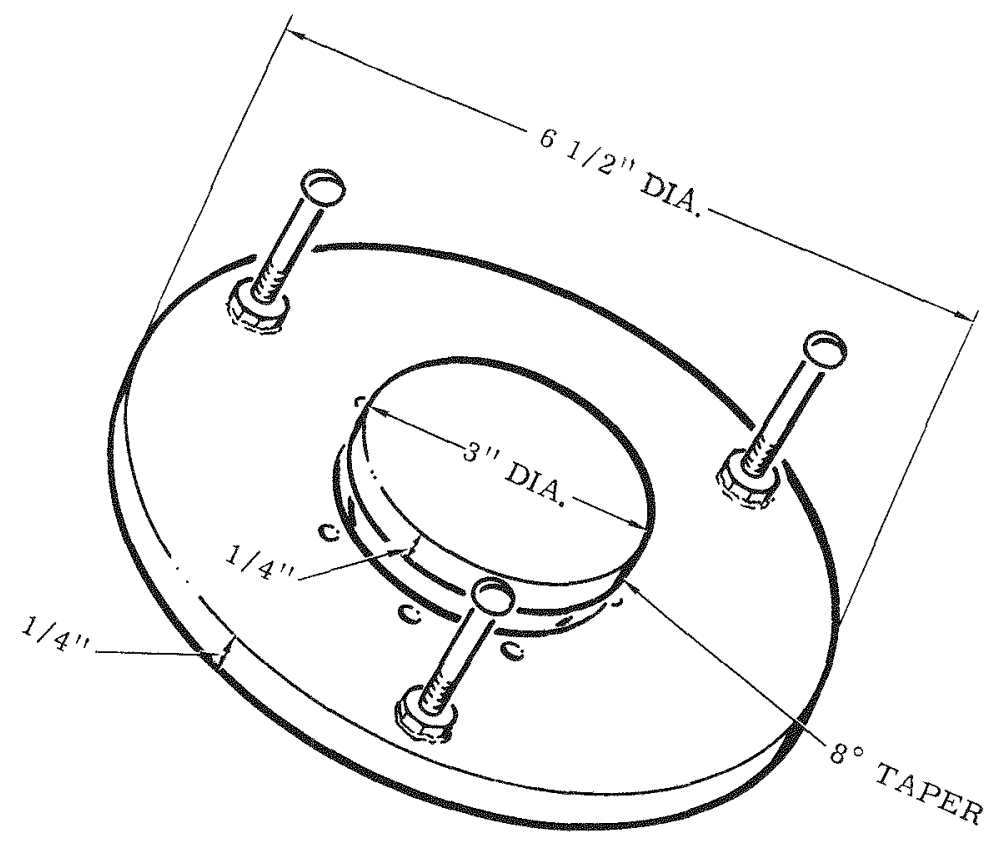

NOTE:

Diameter of impact surface of tapered plug $\cong 2.9$ inches

Figure 4. Tapered Plug Spall Target

The complete spall thresholds in Table $I_{\text {s }}$ parts 1 and 2, are based on tapered-plug shots with negligible edge effects. The spalled piece of each tapered plug is extremely flat and is spalled over its entire surface.

\section{Actual Determination of Thresholds}

To determine the incipient spall threshold, cross sections are cut of samples fired at various low pressures with a particular pulsewidth. These cross sections axe then etched cathodically as discussed in Appendix A. Then the central, edge-effect-free, region of each sample is scanned with the metallograph at $60 \mathrm{X}$ until spall fractures are detected. For certainty they are also scanned at 300X.

The incipient spall threshold, of course, is bracketed by the undamaged sample tested at highest pressure and the sample with spall damage tested at the lowest pressure. Incipient spall thresholds for four different pressure and various pulsewidths may be seen in Figure 2. Clearly, the incipient spall threshold is somewhat arbitrary and dependent upon the etching and optical techniques chosen.

The intermediate spall threshold was determined as follows: The author sent spall samples fired at various intermediate pressures to Dr. Herrmann at MIT. Previously, each of the se samples had been cross-sectioned and etched chemically (see Appendix A). Regretfully, not enough samples were sent to determine the intermediate threshold for the $3 / 4$ microsecond pulsewidth. The intermediate threshold with a 1-1/2 microsecond pulsewidth is shown in Table $I$, part 1. 
Dr. Herrmann cut tension specimens, including the spall plane, from each sample. These specimens were then pulled apart in a tension testing machine. In this way, he measured the residual strength across the spall plane. Figure 5 gives part of his results.

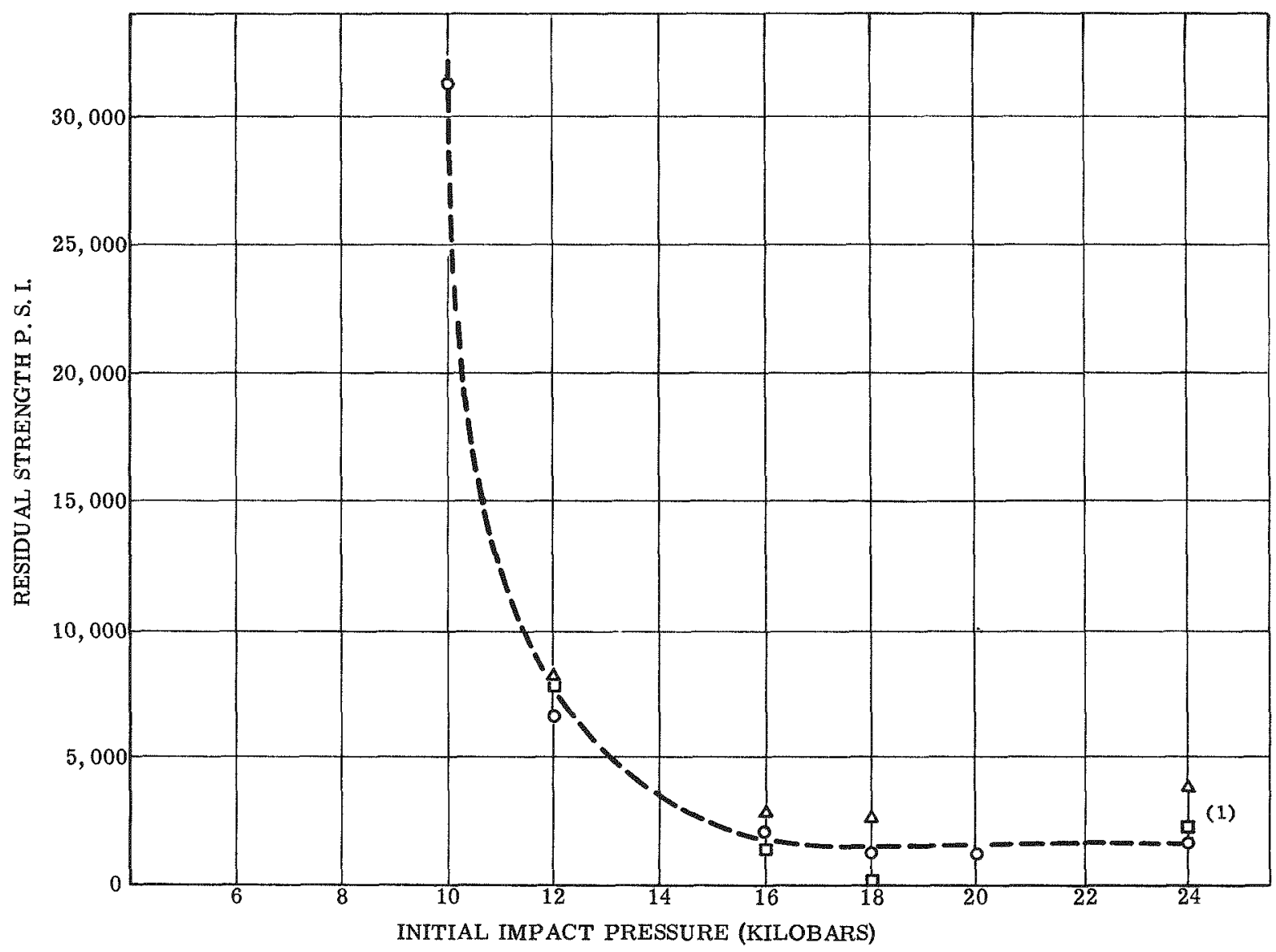

(1) The $24 \mathrm{~kb}$ data were obtained with a grooved target. Edge effects prevented complete separation at $22 \mathrm{~kb}$.

Figure 5. Residual Strength of Targets Using $1.5 \mu \mathrm{s}$ Square Puises *

Essentially, Figure 5 shows that samples tested below six kilobars with the pulsewidths used here have virgin-material strength. Samples tested above six kilobars lose residual strength quite rapidly as pressures approach fourteen kilobars. In fact, most cracks occur between 10 and 12 kilobars initial pressure. Surprisingly, samples tested between sixteen and twenty-two kilobars have a constant residual strength. Of course, samples tested above the complete spall or detachment threshold have zero residual strength. In Reference 20, Dr. Herrmann discusses the rate dependence of the spall process and explains his results. This threshold is not intended to be as sharply defined as the other two. The complete spall threshold is bracketed by the detached or completely spalled sample fired at lowest pressure and the intact sample fired at highest pressure. Certainly the intact sample has severe internal damage. Complete spall thresholds for two different pulsewidths are given in Table I.

\footnotetext{
* This graph by Dr. Walter Herrmann of MIT.
} 
The tensile stress or negative pressure reached in each test can only be estimated at this time. For simplicity, each negative stress is assumed to be equal to the positive stress generated at the impact interface. The positive pressures are calculated with the Hugoniot conservation of momentum equation. And, fortunately, the impact velocities in the data tables have been accurately measured. Therefore, in years to come, when the negative equation of state of copper is known, the pressure data can be improved. Experimental and theoretical methods of deducing negative equations-of-state for metals are being developed in a Sandia-MIT joint effort。 *

In the momentum conservation equation, $\mathrm{P}=\rho \mathrm{U}_{\mathrm{S}} \mathrm{U}_{\mathrm{p}}$, the density, $\rho$, is accurately known to be 8.86 grams $/ \mathrm{cm}^{3}$ for this copper. The particle or material velocity, $\mathrm{U}_{\mathrm{p}}$, is known on each test to within 3 percent. As yet, a lack of time has precluded an accurate determination of the plastic shock velocity, $\mathrm{U}_{\mathrm{S}}$. However, a value of $4.1 \mathrm{~mm} / \mu \mathrm{sec}$ for $U_{S}$ was obtained from two equation of state shots and was used to compute all pressures in this work. As a check, computed pressures were compared to an extrapolation of Walsh's data.21 The computed pressures did not deviate more than one kilobar from Walsh's. Plastic shock velocity is known to increase with pressure, but since the observed thresholds are within a $20 \mathrm{kilobar}$ interval, the increase in shock velocity is negligible.

The same two equation of state shots gave the Hugoniot elastic limit or dynamic yield in compression of copper as about six or seven kilobars. Perhaps by coincidence, this is very close to the incipient spall threshold.

Approximate pulsewidths were obtained by dividing measured projectile plate thickness by the estimated shock velocity of $4.1 \mathrm{~mm} / \mu \mathrm{s}$.

\section{Spall Velocity and Mass Loss}

Velocities of a few spalled pieces were measured with a Fastax camera. Not enough measurements were made to establish a trend. The spalled pieces move with roughly 80 percent of the impacting plate velocity。

McQueen and Marsh ${ }^{5}$ speculate that sublimation may have caused the considerable mass loss in their high-pressure copper spall tests. In these low pressure tests, $1 / 2$ to $3 / 4$ percent mass loss is observed by weighing completely spalled samples. However the colored Fastax films show a copper colored cloud of fragments between the spalled piece and the remaining target. Hence, appreciable sublimation is unlikely at these low pressures.

\section{Relative Spall Thickness}

Thicknesses of detached spall pieces were determined by weighing while the unseparated ones were measured with a Filar eyepiece on the metallograph. Based on the data in Table II, the average projectileto-spall thickness ratio is 1.03 . The scatter of thickness ratios is probably caused mainly by inhomogeneities in the polycrystalline copper.

By making the assumption that the rarefaction also travels as a shock, a relation between the rarefaction-to-shock velocity ratio and the measured thicknesses may be derived. This relation, in conjunction with the data, indicates that the rarefaction exceeds the shock velocity by two or three percent. The detailed calculations are not presented because of the grossness of the treatment.

\section{Conclusions}

The experimental techniques discussed here for copper can be used to determine edge-effect-free spall thresholds in other metals and most nonmetals. The inherent control and accuracy of an air-gun facility exceeds that of a high-explosive facility, although the pressure range is limited with the former. Fortunately, most spall thresholds lie in this limited range.

\footnotetext{
*Report to be published by L. M. Barker and C. D. Lundergan of Sandia Corporation and
} Walter Herrmann of MIT. 
Incipient spall occurs when the input pressure exceeds the compressive elastic limit. This could be indicative of a correspondence between the elastic limits in compression and tension. Also, the residual strength of samples tested between 16 and 22 kilobars is surprisingly constant.

Certain wave properties were important in this program. For example, spall damage depends on pulsewidth in addition to peak stress. And spall thickness measurements indicate that the rarefaction wave is a few percent faster than the shock front. 


\title{
APPENDIX A
}

\author{
METALLURGY
}

\section{Etching Techniques}

The copper used in these experiments was specified as QQ-C-576, cold rolled, and 99.9 percent pure, plate stock. Actual hardness measurements gave averages of 93 on the Knoop scale and 68 on the Rockwell $\mathrm{F}$ scale. The density of this copper was 8.86 grams $/ \mathrm{cm}^{3} 3$

The 24 samples which the author sent to Dr. Herrmann at MIT had been chemically etched with ferricchloride etchant. Unfortunately, rinsing in water and vibrating ultrasonically failed to remove all the etchant from the spal1 fractures. Consequently, the etchant may have continued its attack and lowered the residual strength of the samples.

A far superior method of etching, developed later and used on all incipient spall samples, is cathodic etching. Here, the spall sample is made the cathode of a four kilovolt gap in a chamber containing pure ionized argon. Finally, the positive ions of argon are allowed to bombard the sample for about two minutes. During the bombardment, the sample is in intimate contact with a heat sink to avoid deleterious effects caused by heating.

\section{Bar vs Plate}

All data reported in the tables are based on copper plate stock. Rolling the plate stock elongated and aligned the grains parallel to the subsequent spall plane. Hence the initial spall fractures tended to unite into larger voids.

Contrary to this tendency, the grains of copper bar stock of the same composition were aligned normal to the spall plane. This kept the initial spall fractures from tending to coalesce, thereby raising the spall thresholds. Only a few shots were fired with bar stock, but the meager data indicate that spall thresholds in bar stock would be only a few percent higher than in plate stock. See Figure A-1 for spall fracture in bar and plate stock.

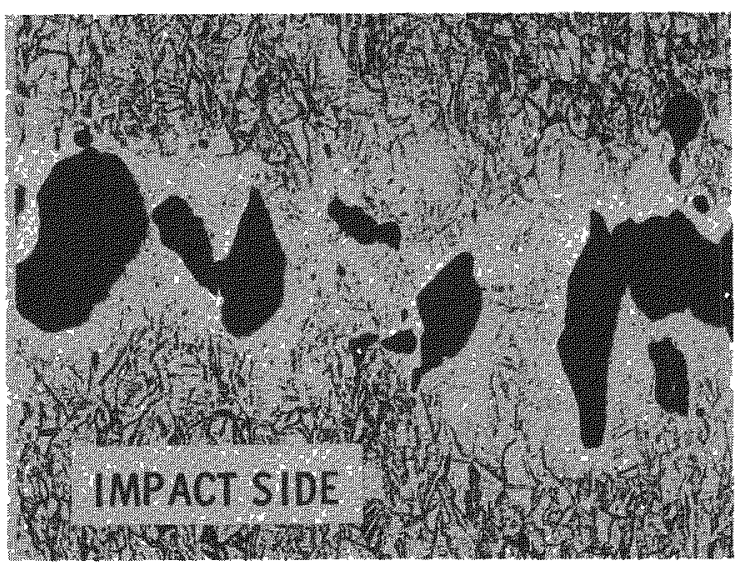

INTERMED IATE SPALL IN COPPER BAR

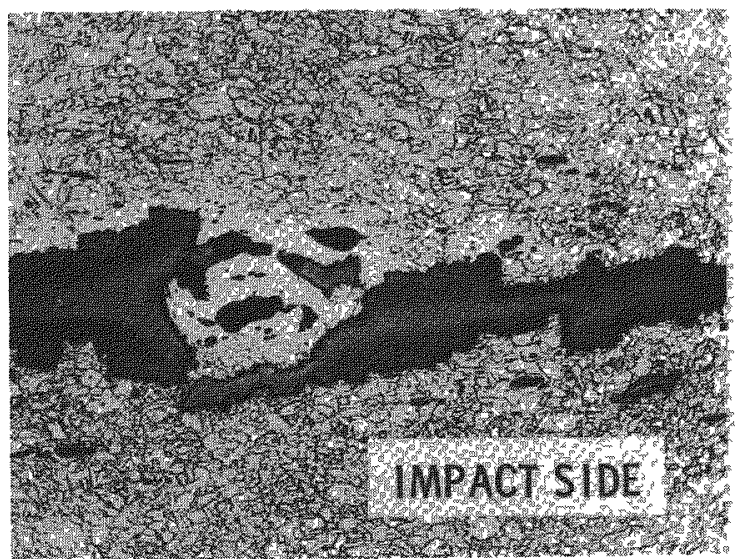

\section{INTERMEDIATE SPALL IN COPPER PLATE}

Figure A-1. Effect of Grain Alignment on Spall 


\title{
APPENDIX B
}

\author{
SPALL PREVENTION
}

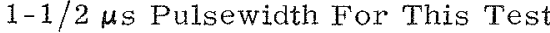

One method ${ }^{19}$ for strengthening against spall is to diffuse either or both of the incoming and reflected waves by drilling conical holes in the target's impact or free surface or both. This wave diffusion causes spall to occur in a series of disconnected regions instead of a continuous plane. Thus, for a piece to separate, it must have enough momentum to shear the copper until all spall cracks are jointed. Evidently this combination spalling and shearing process requires considerably more energy than simple spall. Figure B-1 illustrates how wave diffusion kept half a spall region connected at thirty-two kilobars, while the other half without wave diffusion spalled and separated as expected. Without wave diffusion, both sides of the spall region would have separated at about twenty-four kilobars with the grooved target.

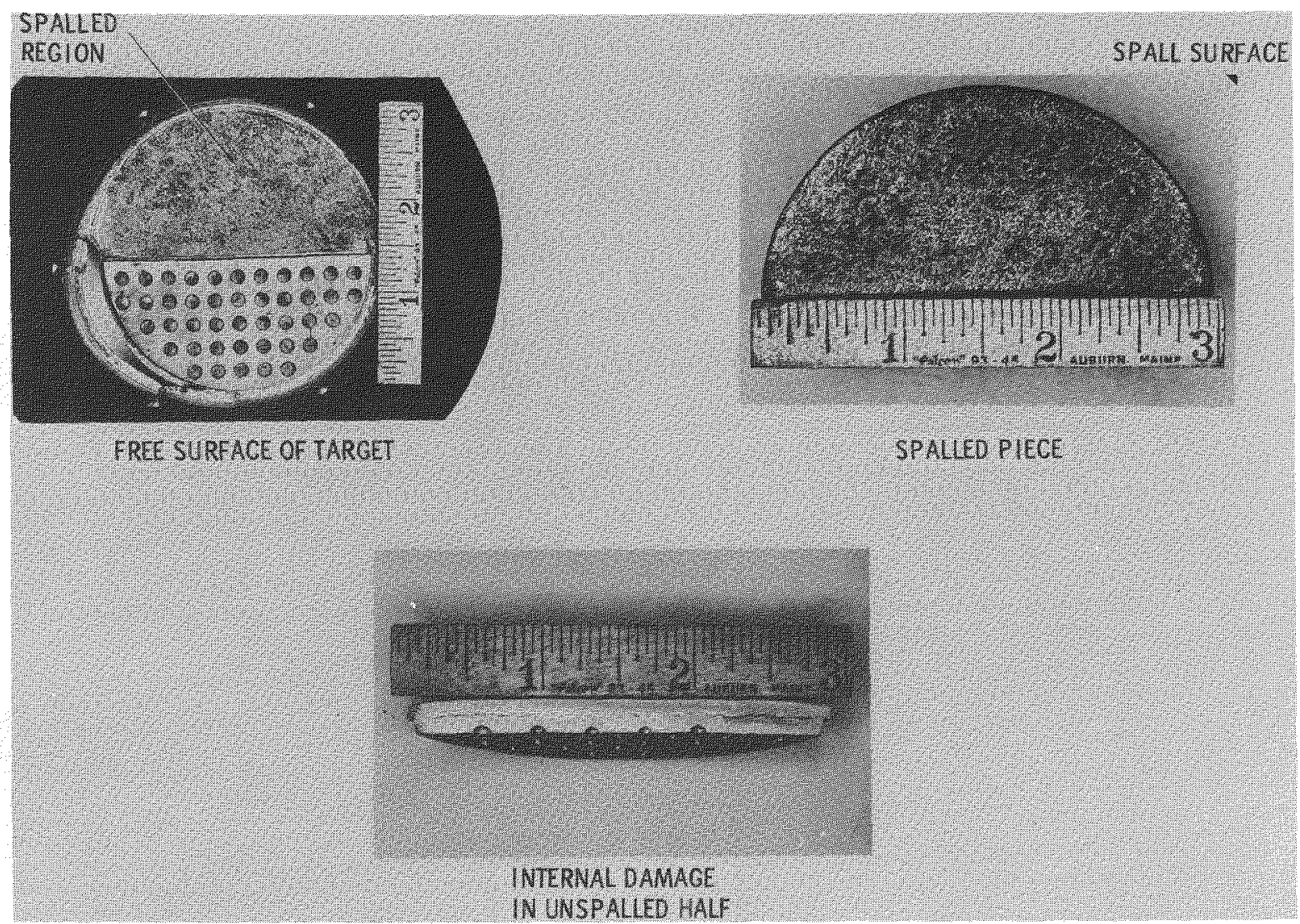

Figure B-1. Spall Prevention by Wave Diffusion

(Impacted at 600 feet/second, $32 \mathrm{~kb}, 1.5 \mu \mathrm{s}$ square pulse, $\mathrm{Cu}$ on $\mathrm{Cu}$ ) 
L. M. Barker, a co-worker, suggested that the holes might give an apparent increase in strength simply by reducing the mass of the spall piece. Thus the spall piece might not break free because of its reduced momentum. However, the reduction of mass proved to be a minor effect. The holes in the eighthinch thick copper spall piece, shown below, reduced its momentum by eight percent. But increasing the pressure from twenty-four to thirty-two kilobars increases the spall piece's momentum by about thirty percent. Therefore, we have a net gain in strength of twenty-two percent and still it did not spall. Hence, the strengthening against spall by wave diffusion is much more significant than a simple reduction of mass. 
APPENDIX C

MISCELLANEOUS FIGURES 


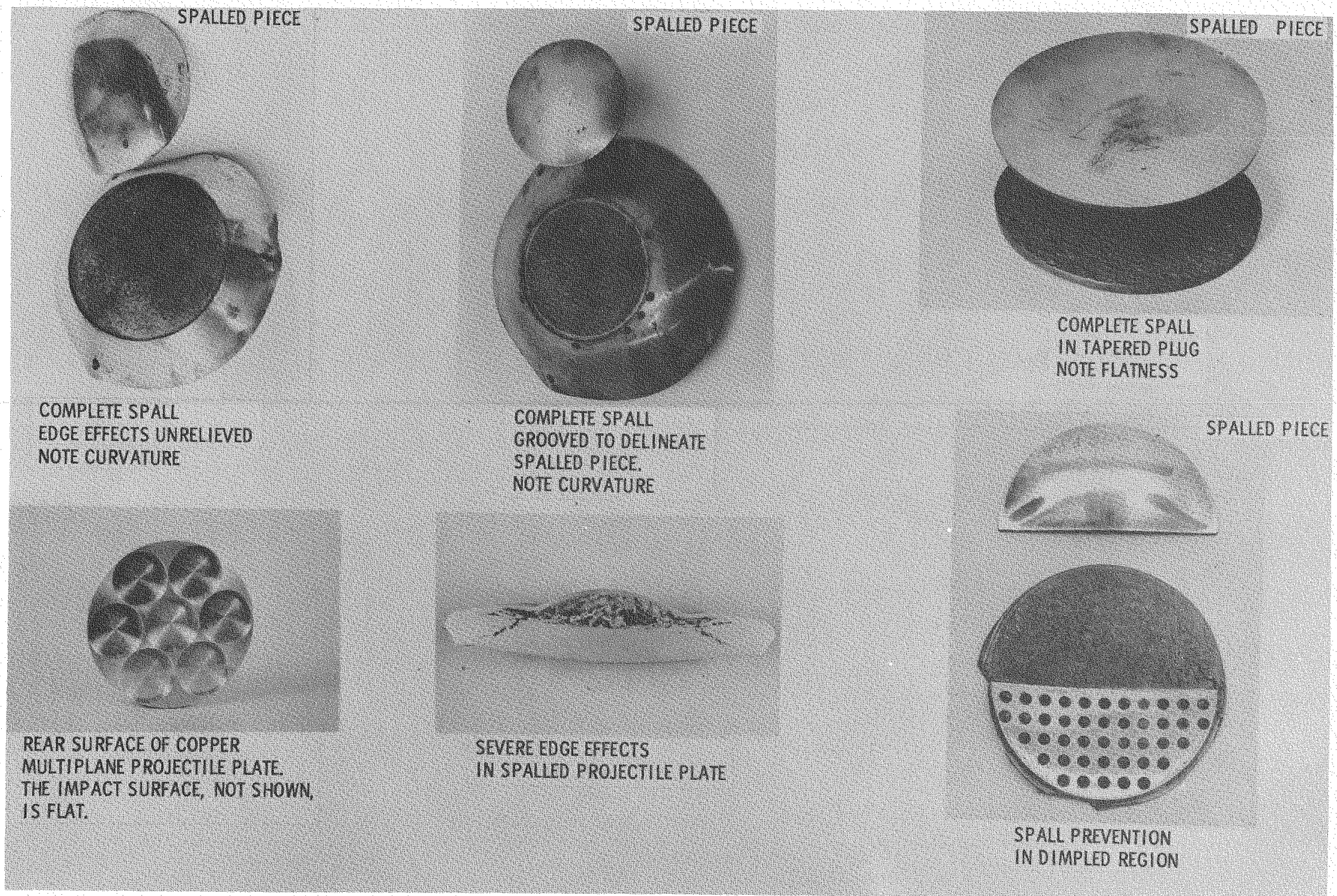

Figure C-1. Miscellaneous Spall Samples 


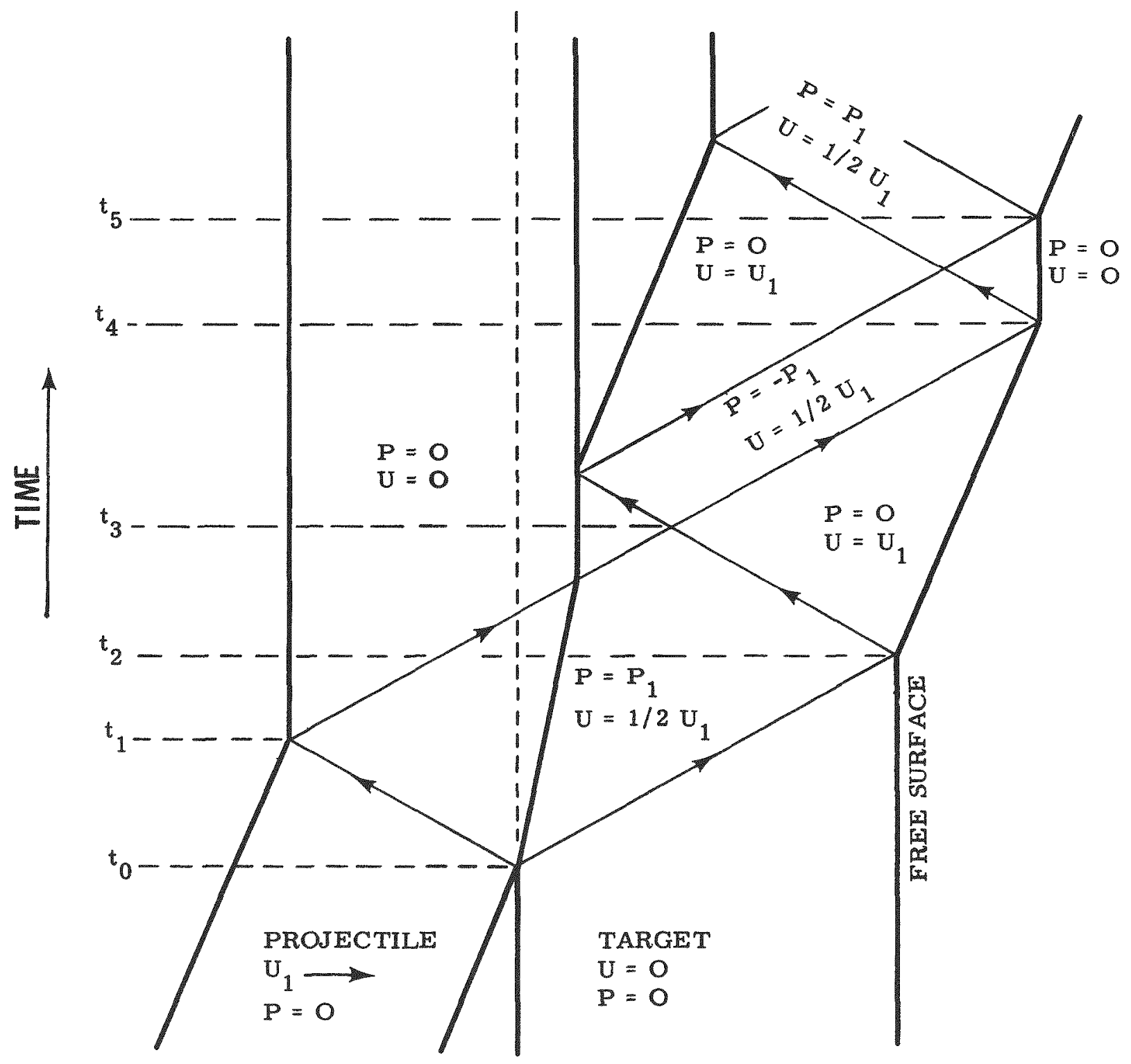

Legend:

$\mathrm{U}=$ Material Velocity

$\mathbf{P}=$ Pressure

$\mathbf{t}=$ Time

Figure C-2. Wave Diagram of a Single Shock Wave Produced by Impact of Two Plates of the Same Material 


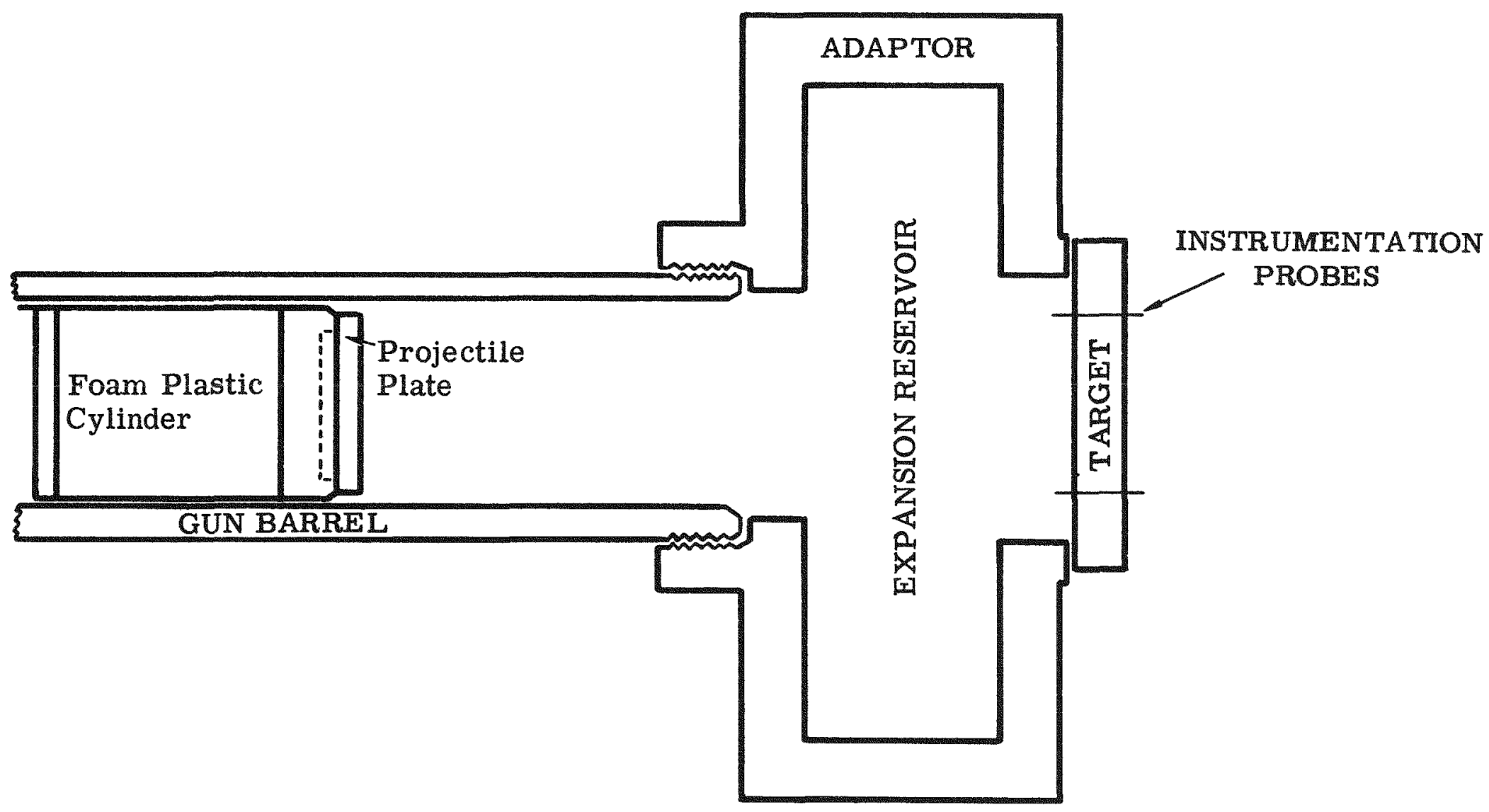

Figure C-3. Diagram of Portion of Air Gun 


\section{LIST OF REFERENCES}

1. J. S. Rinehart, "Some Quantitative Data Bearing on the Scabbing of Metals Under Explosive 4ttack, " Journal of Applied Physics 22, 555 (1951).

2. J. S. Rinehart, "Scabbing of Metals Under Explosive Attack: Multiple Scabbing," Journal of Applied Physics 23, 1229 (1952).

3. J. S. Rinehart and J. Pearson, Behavior of Metals Under Impulsive Loads, (American Society for Metals, Cleveland 1954).

4. M. Dank, J. Gelstein, F. A. Lucy, H. W. Semon, F. Wendt, and F. Jo Willig, The Vulnerability of Structures to Shock Loading at Extreme Altitudes, USAF TR-59-713, July 1959 (Title uncl.; document SRD).

5. R. G. McQueen and S. P. Marsh, "Ultimate Yield Strength of Copper," Journal of Applied Physics 33, No.2, Feb. 1962, pp. 654-665.

6. C. Glass, progress report, "Minutes of the First Meeting of the Working Committee on AFSWC Theoretical \& Experimental Fracture Program," Ballistics Research Laboratory, Aberdeen, Maryland, March 22, 23, 1960, p。39。

7. B. Hopkinson, "The Pressure of a Blow," Scientific Papers, (Cambridge University Press, England, 1921) p。 423 (Evening discussion at the Royal Institution, Friday, Jan. 26, 1912).

8. Jo Oo Erkman, Spalling of Aluminum and Copper, Poulter Lab., Tech。 Report 015-59 (1959).

9. A. A. Griffith, "The Phenomena of Rupture and Flow in Solids, "Trans. Royal Soc. London, Vol. $221 \mathrm{~A}, 1920$, p. 163.

10. A。 A. Griffith, "Theory of Rupture," Proceedings, First International Congress for Applied Mechanics, Delft, 1924, p. 55.

11. K. B. Broberg, "Studies of Scabbing of Solids Under Explosive Attack," Journal of Applied Mechanics 22, 317 (1955).

12. K. B. Broberg, Three Lectures on the Theory of Fracture and Spalling, Colorado School of Mines, Research Foundation, Inc. (Golden, 1959).

13. K. B. Broberg, "Some Aspects of the Mechanism of Scabbing," International Symposium of Stress Wave Propagation in Materials, Interscience Publishers, Inc。, New York (1960).

14. No I. Mott, Fracture of Metals: Theoretical Considerations, "Engineering 165, 16-18 (1948)。

15. D. K. Roberts and A. A. Wells, "The Velocity of Brittle Fracture," Engineering 178 , $820-821$ (1954).

16. R. E. Duff, The Effect of Surface Asymmetries on the Surface Velocity Determined by a Pin Technique, Los Alamos Scientific Lab. Report La-1275, (1951).

17. C. D. Lundergan, A Method of Measuring (1) the Parameters of Impact Between Two Plane Surfaces and (2) the Properties of the Plane Shock Waves Produced, Sandia Corporation Report SC-4421(RR) (1960)。 
18. Jo H. Smith and L. M. Barker, Measurement of Tilt, Impact Velocity, and Impact Time Between Two Plane Surfaces, SC-4728(RR) to be published.

19. Jack Trulio, "Studies of Heterogeneous Materials and Spall, "pp.138-156 in Proceedings of the AFSWC Hydrodynamics Conference, March 1960 (Title uncl; document SRD).

20. Walter Herrmann, progress report, pages 18-36 of "Fracture Program minutes. See reference 6 .

21. J。 M. Walsh, M. H. Rice, R。 G. McQueen, and F. L. Yarger, Shock Wave Compressions of Twenty-Seven Metals. Equations of State." Phys. Rev. 108, 196 (1957).

22. J. S. Rinehart, Practical Countermeasures for the Prevention of Spallation, AFSWC-TR-60-7, (1960).

23. R. A. Plauson, Jo Grimsley, and A. D. Solem, Spall Studies in Copper, NOLTR-61-121, published April, 1962。

24. J. L. O'Brien and R. S. Davis, "On the Fracture of Solids Under Impulsive Loading Con-

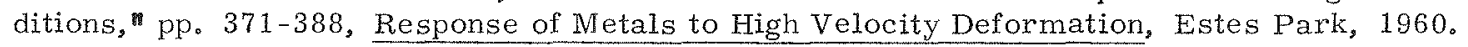


DISTRIBUTION:

UC-25 Metals, Ceramics, and Materials (TID-4500 18th Ed.) (580)

II. F. Carroll, Division of Class., Oak Ridge, Tenn.

$\mathrm{Ph}$. Beatrix, Ingenieur au Commissariat a $1^{8}$ Energie Atomique, 44, Avenue Mozart, Paris $16^{\circ}$, France

A. F. Lucy, GE Valley Forge Space Technology Center, P. O. Box 8555, Philadelphia 1, Pa.

W. H. Andersen, Aerojet General Corp., 11711 Woodruff Ave., Downey, Calif.

E. A. Ripperger, Engineering Mechanics Dept., U of Texas, Austin, Texas

L. C. Gilbert, ASRMDJ-12, Wright-Patterson Air Force Base, Dayton, Ohio

C. M. Glass, Ballistic Research Laboratories, Aberdeen Proving Ground, Maryland

S. K. Golaski., Ballistic Research Laboratories, Aberdeen Proving Ground, Maryland

Commander, AFSWC, Attn: Arthur H. Guenther

Walter Herrmann, Dept, of Aeronautics and Astronautics, MIT, Cambridge, Mass.

C. C. Hsiao, University of Minnesota, Minneapolis, Minn.

Donald Keller, Northrup Corporation, Ventura, Calif.

Dick Wasley, LRL, Livermore, Calif。

Mark Wilkins, LRL, Livermore, Calif.

Bob McQueen, GMX-6, LASL

John S. Rinehart, Colorado School of Mines, Golden, Colo.

Donald G. Doran, Stanford Research Institute, Menlo Park, Calif.

George E. Duvall, Stanford Research Institute, Menlo Park, CaIif.

B. A. Stein, Arthur D. Little, Inc, Cambridge, Mass.

Jack Trulio, LRL, Livermore, Calif.

S. R. Valluri, California Institute of Technology, Pasadena, Calif.

Jerry Wackerle, GNIX-6, LASL

J. M. Walsh, General Atomics, Box 608, San Diego, Calif.

Dave Williams, Kaman Aircraft Corp., Nuclear Div, , Colorado Springs, Colo.

M. L. Williams, California Institute of Technology, Pasadena, California

Dan M. Young, Boeing Airplane Co., Aerospace Division, P. O. Box 3707, Seattle, Wash.

Lou Zernow, Aerojet-General Corp., Downey, Calif.

V. C. Frost, Structures and Materials Dept., Aerospace Corp., P. O. Box 95085, Los Angeles 45, Calif.

W. D. Martin, Pantex, Mason and Hangar, Silas Mason Co., Amarillo, Texas

J. Weertman, Materials Science Dept., Northwestern Univ, Evanston, Illinois

C. F. Bild, 1100

R. R. Sowell, 1110

C. D. Lundergan, 1113 (5)

A. Y. Pope, 7130

R. C. Maydew, 7132

J. H. Smith, 7132-1 (10)

B. R. Allen, 3421-1

M. G. Randle, 3421-3

W. F. Carstens, 3423

Distribution, $3466-1$ (10) 